\title{
Biopolitics of security in the 21st century: an introduction
}

\author{
MICHAEL DILLON AND LUIS LOBO-GUERRERO*
}

\begin{abstract}
This essay addresses two questions. It first asks what happens to security practices when they take species life as their referent object. It then asks what happens to security practices which take species life as their referent object when the very understanding of species life undergoes transformation and change. In the process of addressing these two questions the essay provides an exegesis of Michel Foucault's analytic of biopolitics as a dispositif de sécurité and contrasts this account of security with that given by traditional geopolitical security discourses. The essay also theorises beyond Foucault when it interrogates the impact in the twentieth century of the compression of morbidity on populations and the molecular revolution on what we now understand life to be. It concludes that 'population', which was the empirical referent of early biopolitics, is being superseded by 'heterogenesis'. This serves as the empirical referent for the recombinant biopolitics of security in the molecular age.
\end{abstract}

'. . f freedom is nothing but the correlative development of apparatuses of security.'

Michel Foucault, Security, Territory, Population

\section{Introduction}

Despite the widespread significance of the biopoliticisation of security in the evolution of modern regimes of power, the biopoliticisation of security is a somewhat neglected story. While it is commonly known, for example, that biopower is a form of power over life whose vocation is to 'make life live', ${ }^{1}$ the powerful analytic of security offered by the biopolitics of 'power over life' is nonetheless also a somewhat neglected analytic especially in international relations and security studies. ${ }^{2}$ This

* This article is part of a larger enquiry which originally arose out of Michael Dillon's Knowledge Resourcing for Civil Contingencies, ESRC Research Award (L147251007). It continues through a grant from The Wellcome Trust (Award 080518). The authors also wish to thank Melinda Cooper, Stuart Elden, Paul Fletcher, Mark Lacy, Paolo Palladino and Cindy Weber for their generous intellectual engagement over the issues discussed here.

1 See the introduction to Michel Foucault, The History of Sexuality, Vol. 1: The Will to Knowledge (London: Penguin, 1998). Note especially, however, the forceful injunction which Foucault brilliantly captures in this expression 'to make life live'. Behind it lies Foucault's well-justified hermeneutics of suspicion concerning a security dispositif whose project is to 'make' life live.

2 It is not of course equally well neglected in social theory and political philosophy where two other variants of biopolitics in addition to that initially provided by Foucault have now received widespread attention. These include the Italian School. See, Paolo Virno, A Grammar of the Multitude: For an Analysis of Contemporary Forms of Life (London: Semiotext, e, 2003), and 
article is designed to help redress that imbalance. It does so with a summary account of the biopoliticisation of security which, while drawing especially on the pioneering work of Michel Foucault's lectures of the 1970s, is designed also to revise Foucault's initial theorisation of the biopolitics of security in the light both of the continuing modernisation of populations, and of the impact of the molecular revolution on our very understanding of life.

By seeking, in addition, to develop the theorisation of biopolitics with Foucault beyond Foucault, however, this article offers more than an exegesis of Foucault. It pursues this strategy by asking two questions.

The first is a collection of related questions, initially posed by Foucault, when in effect he asked: What happens to the political rationalities and technologies of power, to the problematisation of security and to the character of security technologies when - taking species life as its referent object - power comes to strategise human being politically as species being? The article goes on to explain how, according to Foucault, biopolitics first evolved around 'population' as its empirical referent object of power. Given Foucault's emphasis on 'empiricities, any engagement of Foucault's biopolitics has therefore to address the category of the empirical referent of 'population', as well as the more generic referent object of biopower which is 'life', and to ask what has happened to population as well as to 'life' in the interim between Foucault's initial interrogation of the biopolitical economy of biopower and the biopolitics of the 21 st century.

This article does precisely that. ${ }^{3}$ It explains how the biopolitics of biopower is necessarily also allied with freedom and what kind of 'freedom' is understood to be at work in it. In explaining precisely what Foucault understands, in addition, by 'security', and how this understanding of security differs from traditional geopolitical accounts of security derived from ontologies and anthropologies of political subjectivity, the article also clarifies why Foucault concludes that biopolitics simply is a 'dispositif de sécurité'. Strictly speaking, therefore, there is no biopolitics which is not simultaneously also a security apparatus. There is no biopolitics of this, or a biopolitics of that. When one says biopolitics one says security, albeit in a certain way.

Biopolitics arises at the beginning of the modern age but it does not spring fully formed at its beginning. It would run entirely counter to Foucault's approach to the analytic of power relations to pretend otherwise. While acknowledging a certain kind of precursor in the pastoral power of the Church, with which it appears superficially

Michael Hardt and Antonio Negri, Empire (Cambridge, MA and London: Harvard University Press, 2001). A second school of biopolitics is that provided by the work of Giorgio Agamben. See especially, Giorgio Agamben, Homo Sacer, Sovereign Power and Bare Life (Stanford, CA: Stanford

University Press, 1998). For critical a engagement of Agamben, see Adam Thurschwell, 'Specters of Nietzsche: Potential Futures for the Concept of the Political in Agamben and Derrida', Cardozo Law Review, 24 (2003), pp. 1193-259, Adam Thurschwell, 'Specters and Scholars: Derrida and the

Tragedy of Political Thought', German Law Journal, 6 (2005); and for a critical exegesis of Agamben in international relations, see Jenny Edkins and Maja Zehfuss, 'Whatever Life', in M. Calarco and S. De Caroli (eds.), Sovereignty and Life: Essays on Giorgio Agamben (Stanford, CA:

Stanford University Press, 2007).

3 This is something which Agamben's biopolitics, for example, specifically does not do. Given its philosophical, and in particular its messianic commitments, it cannot do so. See, for example, Thurschwell, 'Specters of Nietzsche'; Mika Ojakangas, 'Impossible Dialogue on Bio-Power', Foucault Studies, 1 (2005), pp. 5-2; and Michael Dillon, 'Cared to Death: The Biopoliticised Time of Your Life', Foucault Studies, 1 (2005), Michael Dillon, 'Governing Through Contingency: The Security of Biopolitical Governance ', Political Geography, 〈doi:10.1016/j.polgeo.2006.08.003〉 (2006). 
similar but from which it diverges in its specificities, what Foucault begins to draw out is the logic of formation which takes hold when power takes species life as its referent object, and the securing of species life becomes the vocation of a novel and emerging set of discursive formations of power/knowledge. This biopolitical logic of formation also expresses a new and emergent experience of the real. A logic of formation is therefore historical, local and particular. It also installs an ontopolitics as it experiments with novel ensembles or technologies of social practice. However generalised it may become, biopolitics is not itself a universal phenomenon. It is the actualisation instead of a specific historical and, we would argue, evolving economy of power relations.

Such ensembles of practices do not actualise themselves in perfect realisation of their logic. First, because their logic is always a contested epistemic object for them. Second, because things always change in unintended ways. Biopolitical security practices do not articulate a design in nature. They are contingent achievements reflecting the partial realisation of designs which seek to enact 'natures'. In the process, there are slippages and breakages, shifts and revisions, for which the original drivers and concerns of biopolitics no longer account. There is nothing unusual in this. It would be unusual if it did not happen. Mutation of the biopolitical order of power relations has continued to follow transformations in the changing order of [living] things. Such mutation has not merely entailed a change at the level of practice. Any change in practice is simultaneously also accompanied by a change in the experience of the real. In general terms the shift in the nature of the real associated with biopolitics, now, is captured by the term 'emergence'.

It is part of our political discourse to talk in terms of a people, a public, a nation or a state as agents having intentions and expressing a view. The life of species being which Foucault first interrogated in his analytic of biopower was not this life. Empirically speaking, the life which Foucault first interrogated when inaugurating this analytic of the bio-economy of power relations was that of 'population'. A population is not a subject, a people or a public. A population is a cohort of biological individuals. Specifically, from an insurer's point of view, for example, a population is simply a risk pool. Populations are therefore said to display behavioural characteristics and correlations. ${ }^{4}$ The epistemologies of political subjectivity especially in relation to traditional security discourses-are preoccupied with establishing secure knowledge about more or less rational choice, interests, intentions and capabilities, and so on. Even when they cannot realise it, which is always, their regulative epistemological ideal is the establishment of causal law. Conversely, the epistemologies associated with the biopoliticised securing of populations are those concerned with surveillance and the accumulation and analysis of data concerning behaviour, the patterns which behaviour displays and the profiling of individuals within the population. Instead of causal law, such power/knowledge is very much more concerned to establish profiles, patterns and probabilities. Here is an illustration.

On the morning of his 60th birthday, the first birthday card which Mick Dillon opened was from his local Sainsburys store. It congratulated him on reaching this ripe old age and invited him back into the store to collect a free bottle of his favourite

${ }^{4}$ Michael Hardt and Antonio Negri, Multitude: War and Democracy in the Age of Empire (New York: The Penguin Press, 2004), p. 427. 
Shiraz. Anybody who has ever used a 'Nectar' card will therefore understand exactly what we are talking about. Mick Dillon was being biopolitically 'secured' as a customer. Being secured as a customer is one of the very many ways in which biopoliticised security practices now saturate our everyday lives. Most people subject themselves to such everyday security practices most of the time through these and other allied devices; such as, for example, also insurance, pensions, investments, securities and risk. ${ }^{5}$ The kinds of means by which Mick Dillon was secured as a Sainsburys' customer are now integral to the biopolitics of security of all modern states, to the operation of the international political economy and to the very 'social inclusion' of individuals in the local economic life of their communities.

Here, life is distributed, weighed and valued, across a shifting terrain of contingent formation rather than identity production. From a social constructionist perspective, identity is in effect to be written. From a biopolitical perspective, contingency is underwritten through a whole variety of calculative practices, not least of which are those that financial markets call securities. Securitising financially has nothing to do, for example, with making an issue a matter of national or international security. It is not immediately or directly to do with the politics of identity either. Securitising financially is a classic biopolitical strategy which capitalises 'life' by translating contingency into risk and risk into a tradable asset. Biopolitics is therefore not a politics of identity - enacting a self-other dialectic through discursive practices of identity production. It is a complex array of changing mechanisms concerned with regulating the contingent economy of species life. Identity may follow from this, but identity production is not its initial driver.

As we shall see, Foucault identifies 'circulation' as the space of operation of biopolitics. Like all biopolitically driven institutions, therefore, in its preoccupation with the pursuit of economy and profit, Mick Dillon's Sainsburys store is integrally also concerned with circulation. Circulation is concerned with flows, but flows have to be monitored and regulated. Amongst many other effects, the task of monitoring and regulating flows changes the basic routines and practices of governing institutions including, for example, those of borders. Borders have never simply differentiated inside from outside. [It is common, of course, to observe that borders join as well as separate. $]^{6}$ Check-outs operate as Sainsburys' borders. One of the many purposes of check-outs is to profile and measure the behaviour of that cohort of consuming individuals which Sainsburys calls its customers. Operating in cognate ways, state borders now also deploy the same kinds of surveillance technologies to do

5 See, for example, Richard Ericson, Aaron Doyle and Barry Dean, Insurance as Governance (Toronto: University of Toronto Press, 2003); Pat O'Malley, 'Insurance, Actuarialism and Thrift', in Risk, Uncertainty and Government (London: Glasshouse Press, 2004), pp. 117-34; Lorraine J. Daston, 'The Theory and Practice of Risk', in Classical Probability in the Enlightenment (Princeton, NJ: Princeton University Press, 1988), pp. 112-87; Bartha Maria Knoppers, Béatrice Godard and Yann Joly, 'A Comparative International Overview', in M. A. Rothstein (ed.), Life Insurance: Medical Underwriting and Social Policy (Boston, MA: MIT Press, 2004), pp. 173-94; Richard Ericson and Aaron Doyle, 'Risk and Morality', in R. Ericson and A. Doyle (eds.), Risk and Morality (Toronto: University of Toronto Press, 2003); François Ewald, 'Norms, Discipline and the Law', Representations, Special Issue (1990), pp. 138-61; Pat O'Malley, 'Risk and Responsibility', in Andrew Barry, Thomas Osborne and N. Rose (eds.), Foucault and Political Reason: Liberalism, Neo-Liberalism and Rationalities of Government (London: University College London Press, 1996).

6 See, for example, how this and related issues are explored in Joel S. Migdal, Boundaries and Belonging: States and Societies in the Struggle to Shape Identities and Local Practices (Cambridge: Cambridge University Press, 2004). 
similar things. They do not prophylactically secure the state by throwing up a barrier around it. Neither do they constitute an identity for it. ${ }^{7}$ Their task is to regulate the very productive powers of the intercourse transacted by, between and through populations. ${ }^{8}$

Such biopolitical intercourse simultaneously both sustains and undermines itself. Air travel circulates disease as well as tourists, commerce and business. ${ }^{9}$ Similarly, the international financial system may be used to sustain terrorist activities as well as industrial and commercial growth. ${ }^{10}$ Complex national and international infrastructures vital to sustaining the very ebb and flow of biopolitical intercourse are the same mechanisms through which life also threatens itself. Such dangers may not be posed by a malign agent. It is commonly recognised now that they can be a direct function also of the very complex dynamics of the systems themselves. ${ }^{11}$ The war on terror has intensified and amplified these characteristic features of the biopolitics of security, but it did not initiate or invent them. The security problematic posed by biopolitics is therefore not that of violent death at the hands of other men. It is how to make life live. But what has been happening to life?

This article, therefore, asks a second fundamental question: What happens to the biopolitics of security when their referent object - life as species existence - undergoes profound transformation and change? We have already begun to signal what asking this second question does. Asking that question takes the analysis of biopolitics of security beyond the terms and circumstances through which Foucault first interrogated it. The question helps revise Foucault's account of the biopolitics of security, and extend its theorisation to the analysis of the political rationalities and technologies of security which are now common among regimes of biopower which increasingly characterise the 21 st century.

At this point, the article also identifies three critically important developments; developments which are continuing to have a profound impact on the changing character of 'life' as the referent object of the biopolitics of security in the 21 st century. The first is demographic and concerns population. The second is molecular and concerns organic life. The third is digital. It concerns machinic and virtual life. These last two are generically concerned with what might be called the changing vital signs of life and the question of animation - assemblages that display life-like properties. For reasons of space, and because the literature on digitalisation is

7 David Campbell, Writing Security (Minneapolis, MN: University of Minnesota Press, 1998).

8 Marketing strategies do of course aim to develop customer loyalty and identification with products, brands and stores. Indeed cards like Nectar cards are commonly called 'loyalty cards'. There is an extensive literature on brand identity. Again, while acknowledging the manifold practices of power relations continuously leaching into one another to analyse this particular operation of biopower.

9 World Health Organisation, 'Global Health Security: Epidemic Alert and Response. Consensus Document on the Epidemiology of World Health Organisation, May 2003, available at: 〈http://www.who.int/csr/sars/en/WHOconsensus.pdf〉 (2003); See also Richard D. Smith, 'Richard D Smith, Infectious Disease and Risk: Lessons from SARS', Risk Case Studies, Nuffield Trust Global Programme on Health, Foreign Policy and Security, Infectious Disease and Risk: Lessons from SARS (2006).

10 See Thomas Biersteker and Sue Eckert, Countering the Financing of Global Terrorism (London: Routledge, 2006).

11 Classically, see Charles B. Perrow, Normal Accidents: Living with High Risk Technologies (Princeton, NJ: Princeton University Press, 1999). 
already very extensive, we confine ourselves to offering some discussion of the first two only. ${ }^{12}$

Modern populations, for example, have long displayed what many demographers and health specialists now call 'the compression of morbidity'. What that refers to is the way in which illness and death among Western populations is no longer primarily caused by infectious diseases but is now regarded as a function of the risk factors integral to their very modes of existence. If the so-called 'compression of morbidity' refers to the transformation of populations, the molecularisation of biology has profoundly transformed the very modern understanding of 'life' itself. The article concludes its revision of the analytic of the biopolitics of security by arguing that the biopolitics of security in the 21 st century are best conceived as a recombinant biopolitics of what the molecular life sciences would call 'pluripotent' life.

One final caveat also seems to be required whenever the question of Foucault and the analytics of power arise. Foucault never offered, or claimed to offer, a general theory of power. He was quite explicit about this. The assemblages of power which he analysed were those modern assemblages of power which emerged in, and out of, Western Europe from the 17th century onwards. These were concerned specifically with the development of modern forms of knowledge and modern forms of freedom. Many other modern ways of exercising power and domination, many other modern ways of being free, were pioneered within and exercised by Atlantic societies. He never claimed differently. The development of changing formations of power and domination is not confined to the Atlantic basin either, of course, or to modernity. Foucault never disputed these points - neither does this article.

His was instead a novel historical positivity of power relations with a preference for describing mechanisms and interrogating their power effects before generalising principles; although he was not averse to doing this as well by way of summary account and dramatising operational differences in the many modalities that excite and circulate power. In the process, Foucault constantly emphasised the summary and qualified rather than definitive nature of his interrogation of the manifold of power relations which characterise political modernity and its characteristic modes of governance and rule, including that especially of liberal governmentality. ${ }^{13}$ One gets the decided impression that a formation of power was for Foucault always in formation, never a final accomplishment. We try to bring that appreciation to our own interrogation of the changing biopolitics of the 21 st century and its newly emergent recombinant biopolitical economy of security in particular.

Conceived as evolving through a force field of time, in which individuation continuously takes shape and transformation occurs, biological entities understood in these terms will not be secured through the practices traditionally favoured by the

12 There is of course a vast literature on digitalisation of information and communication. This, too, argues for a revision of received understandings of what it is to be a - machinic and virtual - thing. See, for example, however, Eugene Thacker, 'Nomos, Nosos and Bios in the Body Politic', Culture Machine (2005), p. 27; Richard Doyle, Wetwares: Experiments in Postvital Living (Minneapolis, MN and London: University of Minnesota Press, 2003); and N. Katherine Hayles, How We Became Posthuman: Virtual Bodies in Cybernetics, Literature, and Informatics (Chicago, IL and London: University of Chicago Press, 1999).

13 Graham Burchell, Collin Gordon and Peter Miller, The Foucault Effect: Studies in Governmentality (Hemel Hempstead: Harvester Wheatsheaf, 1991), p. 307; Barry, Osborne and Rose, Foucault and Political Reason; Wendy Larner and William Walters (eds.), Global Governmentality: Governing International Spaces (London: Routledge, 2004); Michael Dillon, 'The Security of Governance', in W. Larner and W. Walters (eds.), Global Governmentality (London: Routledge, 2004. 
geopolitical discourses of political subjectivity. They cannot be secured in such ways because, representing a differently understood referent object of both freedom and power, living entities pose a quite different kind of security problematic. For one thing their very presence is not fixed. For another it is their very fructification that is being sought, not their simple protection. In order for living entities to fructify they have to be allowed to do so. Their biological freedom to adapt and change is integral to securing their very existence and the realisation of its potentialities. Securing here is not a condition of possibility of their freedom. It is that regulation of their behaviour which promotes their vital signs of life; specifically these days those concerned with adaptation and transformation. A fundamental paradox thus arises for the biopolitics of security. In order for a living thing understood this way to be secured it has to be allowed - indeed encouraged - to pass out of phase with itself and become something other than what it was in order to continue to live. That is why biopolitics is not initially a politics of identity or political subjectivity. Identity or political subjectivity is not at first the name of the game, which is not to deny that biopolitical security practices are mined as a rich source of novel subject positions: the additional game of applying the cogito-effect to emergence.

That which endures by moving out of phase with itself as it transacts complex negotiations with its environment or milieu is not amenable, however, to being secured by inscription within the boundaries of an identity, a territory or the cogito. Its vital signs of life are precisely those governed by a different operational dynamic of the contingent. It is this which typically invokes biopolitical security practices. The name of the game here is 'capacities for adaptation and change', otherwise known as 'fitness'. It is that which ultimately promotes the very understanding and command of the dynamics of hetero-genesis into the empirical referent of the biopolitics of security of the 21 st century.

\section{The biopolitics of population: from 'Le Genre Humain' to 'Être Biologique'}

When, according to Foucault, modern political power first assigned itself the task of 'administering life', its governing technologies revolved around two poles of life. The one centred on 'the body as a machine: its disciplining, the optimisation of its capabilities, and the extortion of its forces'. ${ }^{14}$ Foucault called this the 'anatamopolitics of the human body'. The second formed somewhat later. It focused on 'the species body, the body imbued with the mechanics of life and serving as the basis of the biological processes: propagation, births and mortality, the level of health, life expectancy and longevity, with all the conditions that can cause these to vary'. These regulatory mechanisms constituted 'a bio-politics of the population'. ${ }^{15}$ These two new modes of governmentality were not antithetical: 'they constituted rather two modes of development linked together by a whole intermediary cluster of relations'. Here, then, as modern power learnt, in its scientific ways, what it meant to be a living species in a living world - 'to have a body, conditions of existence, probabilities of life, an individual and collective welfare, forces that could be modified and a space in

14 Foucault, The History of Sexuality, Vol. 1: The Will to Knowledge (1998), p. 139.

15 Ibid. 
which they could be distributed in an optimal manner' - biological existence was reflected in political existence and power, not simply dealing in legal subjects but with living beings, took 'life and its mechanisms into the realm of explicit calculations and made knowledge/power an agent of the transformation of human life'. ${ }^{16}$ Biopower in particular, Foucault was to elaborate in his lectures, 'deals with the population, with the population as a political problem, as a problem which is at once scientific and political, as a biological problem and as a power's problem' ${ }^{17}$

What Foucault initiated in his analytic of biopower, and what follows here, is not an espousal however of the biopolitics of security. ${ }^{18}$ Neither is it an argument to the effect that all other politics of security and freedom have been displaced by the biopolitics of security. What Foucault originated, and what this article seeks to theorise in a Foucauldean vein beyond Foucault, is an 'analytic' of the biopolitics of security. It is perhaps helpful, then, to state briefly what is meant by an analytic. An analytic of power is an exercise of thought concerned with detailing the operational logics, forces and dynamics at play in a specific configuration of power relations. Since power for Foucault is always a matter of the relations established by a set of practices, specifically those concerned with changing mechanisms of power/ knowledge, a Foucauldean analytic of power is necessarily also an exploration of the forces, logics and dynamics at play in assemblages of such practices. It is important also to explain that for Foucault, as much as for this article, every assemblage of such practices is an assemblage of 'truth telling' which not only seeks to regulate life but also reflects and enacts a certain understanding of 'the real' as it does so. In the process, what Foucault calls a grid of intelligibility is established, which grids of intelligibility simultaneously also become the means by which life is weighed, distributed, valued and found wanting, as well as good. A grid of intelligibility is in short an accounting and a valuing machine. ${ }^{19}$ Such modern assemblages of power/ knowledge will, according to Foucault, also critically interrogate the very ontology to which they give expression. Intelligently remedial in relation to the governmental technologies which they employ, biopolitical security practices simultaneously also explore how 'the real' they presuppose might be better understood and acknowledged. The biopolitical understanding of the real - its experience of the 'real' of living things - is played back into refining the technologies designed to regulate and

16 Ibid., p. 143.

17 Foucault in Michel Foucault, Society Must Be Defended (London: Penguin Books, 2003), p. 245 (henceforth cited as SMD). This is the first of the three lecture series of the 1970s from which we especially draw in this account of biopolitics. The other two were: Michel Foucault, Sécurité, Territoire, Population, 1977-1978, Lectures au Collège de France (Paris: Hautes Etudes, Seuil Gallimard, 2004) recently translated by Graham Burchall and published by Palgrave/ Macmillan as Security, Territory, Population (2007); henceforth to be cited as STP. The third lecture series was Michel Foucault, Naissance de la biopolitique (Paris: Hautes Etudes, Seuil Gallimard, 2004). It too is currently being translated by Graham Burchall and is to be published by Palgrave/ Macmillan as The Birth of Biopolitics (henceforth cited as BoP). See Stuart Elden, 'Rethinking Governmentality', Political Geography, 25 (2006) for a situating and summary account of these lectures.

18 Foucault expresses his hostility to species thinking and allied philosophies of becoming in, 'Theatrum Philosophicum'. See, Michel Foucault, Language, Counter-Memory, Practice (Ithaca, NY: Cornell University Press, 1988), pp. 165-96.

19 Michel Foucault, The Order of Things (London: Routledge, 1989 [1966]), p. 422. See also Stuart Elden's reflections on how this very reduction of the human to the fungible and the calculable, however differently, constitutes the core of the hermeneutics of suspicion to which both Heidegger and Foucault subject the modern project. Elden, 'Rethinking Governmentality'; Stuart Elden, 'Governmentality, Calculation, Territory ', Environment and Planning D: Society and Space (2007). 
capitalise upon it. It is for these, among other reasons, that Foucault referred to the regional ontologies employed by such truth-telling practices, for example those of 'Life', 'Labour' and 'Language' in The Order of Things, as 'quasi-transcendentals' ${ }^{20}$ Although Foucault does not directly address them in this way, 'the event', 'the contingent', 'population' and, as we will see, 'circulation', do all figure more or less prominently as such in his account of biopolitics.

Foucault first taught that the biopolitical promotion of human being as species existence originally developed around the interrogation, classification and statistical analysis of population in the burgeoning towns and cities of France in early-modern Europe. Here, he says, a new political object of governance, a new reality, emerged: that of the population rather than the people.

The life of species being is, however, neither singular nor fixed. On the one hand, biopolitics is critically dependent, epistemically and ontologically, on what the sciences of life say that species life is, what it consists in, what its thresholds are, and on the mechanisms that these make available for intervening into living processes in order to further what Foucault taught was the vocation of biopolitics; the promotion of the productivity and potentiality of species life, abstracting its very vital signs of life the better to utilise them in the further promotion and exploitation of life's potential. Biopolitics is similarly also susceptible to historical transformations in the very character of the populations which it seeks to regulate as well as in the scientific understanding of the very nature of living material as such. ${ }^{21}$ But what has to be understood, first, is a base distinction drawn within the category of 'life' itself.

Intrigued by the mechanisms through which the basic biological features of the human species became the object of political strategy, when Foucault first came to interrogate biopolitics he noted how it differentiated life as species existence from life understood in other ways. Life understood as species existence-espèce humainediffers fundamentally, for example, from life understood as 'le genre humain'.22 The root of le genre humain - gens - refers to the jus gentium of Roman and medieval law. Usually translated as 'the law of nations', and extensively treated in the work of two early-modern international jurists, Hugo Grotius ${ }^{23}$ and Emmerich de Vattel, ${ }^{24}$ important to the development of early-modern national and international understandings of rule and power, the gentium of jus gentium invokes the juridico-political and cultural notion of a 'people' or 'peoples' belonging together in respect of law and custom, not the biological notion of 'species' (the root of espèce, or être biologique), in which the principle of belonging together is furnished by shared biological properties. The move from gentium to espèce thus effects a transformation in the very understanding of what it is to be a living being and correspondingly of the governmental regulation of such a living thing.

What followed in that shift from gentium to espèce was a transformation not only in the referent object of power relations but also in the very mechanisms by means of which power operates and circulates. Specifically, in relation to espèce humaine,

${ }^{20}$ See, especially, Foucault, The Order of Things (ch. 8), 'Quasi-transcendental because they are positioned outside practices by the work of practices themselves'.

21 Foucault, Sécurité, Territoire, Population.

22 Foucault, Naissance de la biopolitique.

23 Hugo Grotius, De Jure Belli ac Pacis Libri Tres (Oxford: Clarendon Press, 1925 [1625]).

24 Emmerich De Vattel, The Law of Nations or Principles of the Law of Nature Applied to the Conduct and Affairs of Nations and Sovereigns (Philadelphia, PA: T. \& J.W. Johnson \& Co., 1883). 
power comes to be exercised on, in and through the biological mass which constitutes the 'species', rather than the juridico-political and cultural processes of belonging and rule said to constitute the gens of gentium, or of 'le genre humain'.25

\section{Le dispositif de sécurité}

Foucault began a lecture series entitled Security, Territory, Population (STP), on 11 January 1978. Announcing the title of his lectures, and cautioning that while his enquiry would focus on the set of mechanisms through which the basic biological features of the human species became the object of political strategisation he was not concerned with a general theory of power, Foucault first posed the obvious question: "What are we to understand by "security" '? His answer was an unusual one. He offered no general theory of the universal value of security. Nor did he proclaim it as a general necessity for life. He began instead, in typical Foucault fashion, to talk about certain specific mechanisms which emerged at the start of the 18th century. We have to reconstruct Foucault's understanding of the biopolitics of security both from his account of these technologies and his more general understanding of the process of problematisation. ${ }^{26}$

Before security can become a concept, a value or a valuing process from a Foucauldean perspective, it must first be inscribed as a problematic. Consequently, different problematisations of security will be comprised of different discourses of danger. Different discourses of danger will revolve around different referent objects of security, such that different referent objects of security will give rise to different kinds of governmental technologies and political rationalities. Such problematisations will be derived from the operation of specific complexes of power/knowledge. Different assemblages of power/knowledge will themselves also be comprised of different mechanisms, techniques, instrumentalities, rationalities and discursive formations. The problematic of security posed by 'life', for example, will not be the same as that posed by the 'human' (anthropos), by political territoriality (la patrie, motherland, fatherland), or by sovereignty (Volk, Reich, Fuehrer, people, or demos). Neither will the security apparatuses that develop around these different referent objects.

Modern times have been distinguished by at least two great problematisations of security. Foucault retells the story of the one (geopolitics) as he introduces his novel account of the other (biopolitics). ${ }^{27}$ The first, revolving around the referent object of

25 See Jens Bartelson, A Genealogy of Sovereignty (Cambridge: Cambridge University Press, 1995), p. 317.

26 Michel Foucault, 'Problematics', in S. Lotringer (ed.), Foucault Live, New York (New York: Semiotext(e), 1996); Michel Foucault, 'On Criticism', in L. Kritzman (ed.), Michel Foucault, Politics, Philosophy, Culture (London: Routledge, 1988); Michel Foucault, 'Polemics, Politics, and Problematisations: An Interview with Michel Foucault', in P. Rabinow (ed.), Michel Foucault: Essential Works of Foucault 1954-1984: Vol. 1, Ethics (London: Penguin, 1994), pp. 111-19.

27 It is surprising how conventionally Foucault tells this story. Contrast it, for example, with historical sociologists like Anthony Giddens, Social Theory (Cambridge: Polity, 1987), and Niklas Luhmann, Risk: A Sociological Theory (New York: Walter de Gruyter, 1993), p. 236. Contrast it also with that told by political theorists like Tilly (Charles Tilly, Peter B. Evans, Dietrich Rueschemeyer and Theda Skocpol, War Making and State Making as Organized Crime (Cambridge: Cambridge University Press, 1985), p. 85; and anthropologists like Talal Asad and Inc ebrary, Formations of the 
sovereign territoriality has been that traditional geopolitical narrative of security which emerged with the establishment of the European state system following the Peace of Augsburg and the Treaty of Westphalia. This military strategic international relations discourse of security came to dominate our modern discourses of security. It articulates what amounts to a needs or value hierarchy in which security is posited as a universal value that is foundational to the very possibility of individual and collective life. Politics emerges from a social contract, founded in this needs hierarchy. It takes the form of a protection racket in which loyalty to state authority is derived from the threat of insecurity said to follow from not having the protection of the state; which apparatuses, in practice, do most of the threatening. The state must therefore always secure its monopoly of the legitimate use of force as the primary security provider. In order to do so it must similarly also monopolise the legitimate definition of threat on the basis of which its claim to monopolise the legitimate use of force is ultimately grounded. Such an account of security has ramified into a whole variety of subsidiary concerns including, for example, civil/military relations; the relative mix of military and other forces which state power (hard and soft) must deploy; the impact of the emergence of international and non-state actors on the state security system; and an irresolvable 'level of analysis' debate concerning the radically undecidable relation between individual and collective security.

Every traditional geopolitical discourse of security invokes security as the limit condition. War in particular operates as the privileged locus of the real for traditional security analysis; the reality said to trump all other realities in the hierarchy of values and needs that underpin its traditional geostrategic discourses. War here is, of course, construed as one of the instrumental means available to the state as actor. In an earlier lecture series pursuing these themes, however, Foucault controversially reverses Clausewitz's dictum that war is the extension of politics by other means. ${ }^{28} \mathrm{He}$ argues instead that war is not an instrument available to a political subject, but a grid of intelligibility from which modern accounts of liberal political subjectivity, in particular, arise. One might therefore gloss Foucault, here, and say that security discourse is the logos of war expressed as a logos of peace. In that sense, political modernity is the extension of war by other means; global liberal governance, especially, once it becomes the only remaining standard bearer of political modernity as a governmental project.

Thus, while Foucault's analytic of the biopolitics of security typically focuses on micro-practices it is important to underline that this analytic articulates a qualitatively different problematisation of security to that which characterises geopolitics. The distinction is not, in short, founded on the basis of a naive level of analysis distinction between macro and micro practices. These two security analytics do not inhabit the same plane of analysis, albeit they coexist and continue to correlate throughout the history of political modernity.

Secular: Christianity, Islam, Modernity (Stanford, CA: Stanford University Press, 2003). Political theologians are especially hostile to the received account. See for example, William T. Cavanaugh, Theopolitical Imagination (London: T. \& T. Clark, 2002), and John Milbank, Theology and Social Theory: Beyond Secular Reason (Oxford: Basil Blackwell, 1993). The political theology of the modern state is a neglected topic, one whose significance has grown considerably with advent of the so-called war on terror. A notable exception is Paul Fletcher, 'The Political Theology of the Empire to Come', Cambridge Review of International Affairs, 17 (2004), pp. 49-61.

28 Foucault, Society Must Be Defended. 
It is nonetheless difficult, however, to sustain the privileging of the micro over the macro which Foucault ordinarily champions in his various analytics of power, because the problematisation of security provides such a powerful point of intersection between geopolitical and biopolitical security analysis. With discourses of security, the micro-political regularly becomes the macro-political; when minor infringements of codes of normalisation, to do especially these days with religious dress codes for example, become incitements to political and nationalistic fervour, and when macro-political calls to nation cash-out into the detailed inscription of everyday conduct. This point was noted by Colin Gordon, for example when he referred to security as a 'specific principle of political method and practice' which joins the governing of the social body to 'proper conduct' of the individual, to the governing of oneself. Foucault also referred to it as the process of internal colonisation. ${ }^{29}$ There is thus no geopolitics that does not imply a correlate biopolitics, and no biopolitics without its corresponding geopolitics. Giorgio Agamben states this point succinctly: 'It can even be said that the production of a biopolitical body is the original activity of sovereign power.' 30

Take, for example also, the ways in which Malthus' population science was recruited into racial geopolitical projects in the nineteenth century. Consider how racialist doctrines informed European imperialisms (liberal as well as autocratic). Note, thirdly, how racial 'science' informed German geopolitics throughout the first half of the twentieth century. Spatiality was directly linked there to race through 'Raum' and 'Lebensraum'; where 'Raum' constituted the very geopolitical project required for species existence. ${ }^{31}$ Within liberal regimes of power today, molecular biopolitics is now also being invoked to encourage the return of eugenics. ${ }^{32}$

What is common throughout traditional geopolitical security discourse is, however, what we might best call a prophylactic interpretation of the security problematic. Security is essentially posed as a protective or preservative measure thrown around a valued subject or object, which subject or object is presumed to exist prior to, and independently of, the security practices which claim to act in their welfare. The entire edifice of modern war, diplomacy, Macht, Realpolitik and raison d'état was raised and continues to function on this basis, with significant revisions and additions following the rise of liberal internationalism in the 20th century. Students of international relations have long noted, however, that security practices themselves are instrumental in constituting the very subjects and objects which they claim to secure. ${ }^{33}$ It is evident also of course that security cannot simply be an assemblage of protective devices since you cannot secure anything without first knowing what it is that you are securing. Even traditional geopolitical security mechanisms must therefore also be comprised of complex epistemic schemas as well. Thus geopolitical

29 Collin Gordon, 'Governmental Rationality: An Introduction', in C. Gordon and P. Miller (eds.), The Foucault Effect: Studies in Governmentality (Chicago, IL: University of Chicago Press, 1991.

30 Agamben, Homo Sacer, Sovereign Power and Bare Life, p. 6. One has to understand that for Agamben sovereign power is a manoeuvre which expresses the logic of sovereign law, not a metaphysics of power.

31 Dan Diner, 'Knowledge of Expansion: On the Geopolitics of Klaus Haushofer', Geopolitics, 4 (1999), pp. 161-88, Geardóid O'Tuathail, Critical Geopolitics (London: Routledge, 1996).

32 Nicholas Agar, Liberal Eugenics: In Defence of Human Enhancement (Oxford: Blackwell, 2004), Catherine Mills, 'Biopolitics, Liberal Eugenics and Nihilism', in S. DeCaroli and M. Calarco (eds.), Sovereignty and Life: Essays on the Work of Giorgio Agamben (Stanford, CA: Stanford University Press, forthcoming).

${ }^{33}$ Campbell, Writing Security. 
power/knowledge is not only concerned with the instruments of statecraft - arcana imperii-it has also to concern itself with making the very subject or object to be secured transparent to knowledge as well: hence, its allied and expanding concern with culture and identity as well as science and technology, for example, in addition to the early biopolitical technologies of statistics and logistics. ${ }^{34}$

\section{The aleatory biopolitical economy of population}

Biopolitics of security are, thus, different from other security practices. Whereas the law, for example, proscribes certain behaviour, and carceral intuitions install panoptical systems of disciplinary surveillance in the execution of the correction prescribed by law, Foucault draws attention to other mechanisms that were being extensively developed, especially from the beginning of the 18th century onwards. These were concerned neither with the practices of the law or the disciplining of bodies. They were concerned instead with the distribution and statistical patterning of behaviour. Typically they began by asking for example: What is the average rate of criminality for a certain type of human being - male/female, young/old - in a given town or region, in respect of certain crimes and so on? What other factors might be correlated with the incidence of such behaviour including, for example, social crises, famines or wars? What factors correlate in particular with the rise and fall of the incidence of such conduct? ${ }^{35}$

We might say that such mechanisms were generically concerned with mapping the incidence of contingent behaviour and correlating it with a whole variety of environmental and biological factors. These practices, Foucault says, were not characteristic either of the legal code or of disciplinary power mechanisms. ${ }^{36}$ Instead they constituted what he called an apparatus or dispositif of security. Foucault did not claim that these devices were novel. They were not. Neither did they cancel out geopolitical sovereign juridical and disciplinary forms of power. He observes instead that while the progressive expansion of legislative measures, decrees, regulations, and circulars fostered the deployment of these mechanisms of security, since their introduction introduced more 'criminality' and therefore offered an incitement to its biopolitical analysis, biopolitical security mechanisms increasingly also relied upon data derived from the intensification and extension of increasingly novel forms of counting, accounting and surveillance. These were stimulated as much by civil and commercial as they were by juridical or military-logistical concerns. ${ }^{37}$

${ }^{34}$ Classically, see William Petty, Political Arithmetick (London: Printed for Robert Clavel at the Peacock, and Hen.Mortlock at the Phoenix in St. Paul's Church-yard (1690), p. 104; available at: 〈http://socserv2.socsci.mcmaster.ca/ econ/ugcm/31l3/petty/poliarith.html〉.

35 Michel Foucoult, Security, Territory, Population (London: Palgrave Macmillan, 2007), pp. 1-4.

${ }^{36}$ Foucault, Secirity, Territory, Population, Lecture 1.

37 See Ian Hacking, The Taming of Chance (Cambridge: Cambridge University Press, 1990), p. 256; Ian Hacking, 'How Should We Do the History of Statistics?', in C. G. Graham Burchell and Peter Miller (ed.), The Foucault Effect: Studies in Governmentality (Hemel Hempstead: Harvester Wheatsheaf, 1991), pp. 181-95, Ian Hacking, 'Biopower and the Avalanche of Printed Numbers', Humanities in Society, 5 (1982), pp. 279-95, Ian Hacking, 'Making up People', in T. Heller et al. (eds.), Reconstructing Individualism (Stanford, CA: Stanford University Press, 1986), pp. 222-36, Ian Hacking, The Emergence of Probability (Cambridge: Cambridge University Press, 1975). 
These biopolitical security mechanisms were therefore not confined to documenting the contingent correlations of criminality and its repression. Since they revolved around the advent of power relations which took the life of species being as their referent object, they were generically concerned with species being and therefore also with economy, health and medicine as well. Indeed, the biopolitical problematisation of security revolved around economy as it also introduced a general biologisation of security discourses; including health and medicine, especially, within the ambit of security thinking. This development was to become widespread by the beginning of the 21 st century. It is not confined to the so-called civil sectors of society either. It is now also common throughout much contemporary military strategic discourse. The current 'Revolution in Military Affairs' (RMA) is, for example, not simply a Military Technical Revolution characterised by the informationalisation of weapon systems and military force structures, combined with the correlate weaponisation also of information. A significant transformation in the 'equipmentality' of security and war, to use a Heideggerean expression, it is very much also a transformation in military strategic cognition throughout which biologised thinking, together with health and medical analogies, abound..$^{38}$

Thus, Foucault explains how, whereas disciplinary power/knowledge, enframed the danger posed by plague in terms of the practices of confinement, biopolitical security practices addressed small pox and the threats posed by other infectious diseases in a quite different way at the beginning of the 18th century. The security problematic which these posed was addressed less in terms of exclusions than in terms of how to fashion modulated and targeted strategies for combating endemic diseases; which strategies derived from the analysis of the contingent distribution patterns which epidemics were found to display as they coursed their ways through populations. ${ }^{39}$

Such biopolitical mechanisms or security technologies were characterised by a number of distinguishing features. First and foremost they were preoccupied with the aleatory. They were in other words concerned with the fundamentally contingent character of behaviour and the contingent correlation of behaviour with an (in principle) infinite variety of correlate factors. ${ }^{40}$ The second was a preoccupation with economy (STP and BoP). Seeking to map the correlations of contingent behaviour, these mechanisms were concerned to ask about the cost of behaviour; in particular asking, for example, if the cost of correction exceeded the cost of the criminality. From that followed an additional concern with applying cost-benefit calculus to different polices and with the modulation of such policies looking to establish a band-width of the acceptable. Basically, Foucault says, the fundamental question was

38 Martin Heidegger, Being and Time (Southampton: Basil Blackwell, 1962), p. 589. Typically, see the following: David and Thomas Czerwinski Alberts, 'Complexity, Global Politics and National Security', (1997); David Alberts, John J. Gartska and Frederick P. Stein, 'Network-Centric Warfare: The Face of Battle in the Twenty-first Century', (1999); John Arquilla and David Ronfeld, In Athena's Camp: Preparing for Conflict in the Information Age (Santa Monica, CA: Rand Corporation, 1997); Alan Campen, Douglas Dearth and Thomas Goodden (eds.), 'Cyberwar: Security, Strategy and Conflict in the Information Age' (Fairfax, VA: AFCEA International Press, 1996); Thomas Czerwinski, Coping with the Bounds: Speculations on Non-Linearity in Military Affairs (Washington, DC: NDU Press, 1998).

39 Foucault, Security, Territory, Population, pp. 1-2.

40 Ibid., pp. 1-2. 
economic; the economic relation, for example, between the cost of repression and the cost of delinquency.

He then went on to itemise a variety of other features. In addition to their preoccupation with the aleatory and the economic, biopolitical security technologies were also distinguished by what Foucault called their space of operation. ${ }^{41}$ If economy was one of the emergent quasi-transcendentals of biopolitics, its space of operation was not defined by the usual geo-economic preoccupations with global regions, national territories, strategic resources and strategic cities or other sites of military strategic and geo-economic significance. At first, he says, the space of operations characteristic of biopolitical security technologies was that provided by 'population'; where population served in effect as both datum and source of additional data. 'Population' thus came to offer a new reality to power/knowledge. Security mechanisms, as Foucault described them here, statistically mapped the contingent behavioural characteristics of populations. They did so guided by some basic questions of economy: distribution and cost-benefit. They also acknowledged a certain material independence of this space of operation from the techniques which began to interrogate it. Population and its sub-fields, were not only accorded an objective status by the very 'sciences' which gave them specificity, their associated biopolitical security mechanisms encouraged regulatory policies informed by what was made known through the scientific interrogation of the independent dynamics, laws and regularities which populations displayed; and which population science sought to make more widely available.

As the Security, Territory, Population lectures in particular advanced, however, it nonetheless also became clear that population was for Foucault embedded in a much wider and more generic space of operation. Foucault simply called this space of operation, 'circulation' - circulation in the widest and most generic sense of the term. Within that generic concern with circulation, biopolitical security mechanisms also concerned themselves with the incidence of possible 'events'. In that they nonetheless also began to tell a tale about the real. That the real made available through the optic of living things was itself 'evental'. That is why events come to be understood biopolitically not only as the temporal uncertainties which occur in and through the very forces and conduits which comprise the circulation of species life. These may be things that one will want to prevent before they happen; including for example scourges such as scarcity or 'dearth' (la disette). They may also be things that one might want to engineer; prosperity. Events reflected the very eventalness of species existence as such. Hence the Being of species being is complexly bound-up with varying philosophies of the event. ${ }^{42}$

The general problematic with which these biopolitical security techniques of population became preoccupied was thus the regulation of circulation, including not

41 A classic philosophical review of figuration of space can be found in S. Edward Casey, The Fate of Place: A Philosophical History (London: University of California Press, 1998). Stuart Elden is especially acute in his analysis of how Foucault understands space and in his relation of that understanding to Heidegger. See Stuart Elden, Mapping the Present: Heidegger, Foucault and the Project of a Spatial History (London: Continuum, 2001).

42 This point is more implicit than explicit in Foucault's analysis. He was intrigued by the Epicureans and the Stoics and, in particular, by Gilles Deleuze's philosophy of the event. See in addition Miguel de Beistegui, Truth and Genesis: Philosophy as Differential Ontology (Bloomington, IN: Indiana University Press, Combined Academic, 2004); Michel Serres, The Birth of Physics (Manchester: The Clinamen Press, 2000). 
simply, for example, the freeing of circulation and the unblocking of log-jams, but more generically also with security the problem of differentiating good circulation from bad circulation. Free circulation came to be generally favoured - specifically, in one of the examples which Foucault examines, the free circulation of grain through market mechanisms in order to avert famine. But the security problematic posed by the regulation of species existence in these specific ways was not simply that of maximising the liquidity or regulating the viscosity of circulation. Here the ambiguous, or dual, nature of circulation as the space of operation for biopoliticised security practices emerges most clearly.

While in their emergent preoccupation with the economy of contingent distributions, biopolitical security techniques were generally well-disposed towards laisserfaire, effective regulation of laisser-faire nonetheless also required an increasingly sophisticated knowledge of circulation if subtly crafted interventions were to profit from the force of the independent dynamics of circulation, contingency and economy - in the form, for example, of markets. What was required were the means by which circulation which was desired could be distinguished from circulation which was not. In effect, the security problematic of circulation as the generic space of operations for these new biopolitical security mechanisms posed itself in terms of differentiating good circulation from bad circulation. It also posed itself in terms of the balance to be struck between too little and too much regulation of the manifold circuits of interchange which characterises the life of species existence. These dilemmas were to become the classic dilemmas of an expanding system of biopower relations distinguished by the manifold ways in which it encouraged biopolitical self-governance via contingency management as the principal means both of securing the welfare of population and their everyday self-rule. ${ }^{43}$

It is also important to underline what distinguishes 'economy' here in Foucault's account-something which preoccupies The Birth of Population (BoP) lectures in particular. Foucault does not approach the problematic of economy by positing the existence of an economic subject distinguished by rationally calculated utility. Once more he attends first to specific practices such as those which emerged to deal, for example, with the problem of famine. Scarcity - in effect a quasi-transcendental for capitalist economics - emerges for Foucault against a more ancient background that of 'fortune' - in which man's evil also figured. As Foucault explained, fortune good or bad - was never simply an acknowledgement of impotence. Every rendition of uncertainty or accident takes place against some account of the real, and provision is always made within each account for some means of address to chance, including within its ambit some measure of redress also for its effects. ${ }^{44}$ Chance is therefore always a political and moral concept which arises in the context of changing cosmologies of being. However chance is figured, it is always figured as an integral part of some political and moral economy. As the modern developed its increasingly calculative ontopolitics of existence, its account of fortune progressively became a function instead of the kind of statistical security techniques which Foucault

43 It will not escape the attention of those documenting the War on Terror Homeland Security and National Resilience strategies that these all closely revolve around such a way of problematising security. See, for example, Michael Dillon, 'Globalisation in the 21st Century: Circulation, Complexity and Contingency', ISP/NSC Briefing Paper 05/02 (London: Chatham House).

44 Machiavelli's account of Fortuna is a classic case in point: Niccolo Machiavelli, The Prince (Oxford: Oxford University Press, 2005). 
discusses in these lectures - namely those concerned with the regulation of behaviour through the analytic of its contingent distribution. Fortuna chance and destiny became contingency. With the advent of more precise mathematical techniques, specifically probability, contingency was increasingly commodified. Contingency commodified became 'risk'. Economy seems then to derive for Foucault from an originary preoccupation with the specificities of circulation, distribution and contingency management (STP and BoP). A second feature which distinguishes the way economy plays out in Foucault's analytic of biopolitics is the emphasis on fungibility - the infinite substitutability of one thing for another in the circulation or intercourse of living things made available by the advance of the calculability of circulation as such.

In ways which anticipate later modern accounts of the function of global cities, the early modern town, for example, was conceived by biopolitical security technologies as a node in a network of many circulatory connections and practices subject to a plurality of possible correlations and events. ${ }^{45}$ Species life in general thus emerges as a manifold in Foucault's account and its biopolitics of security deal with the contingent multiplicities engendered not only by the way that species life circulates, but also by the manifold of things, such as disease for example, which, in addition, circulate through life. Every biopolitics of security, we might therefore now add, has an allied microbiological politics of all of the things circulated in its turn by life. ${ }^{46}$ Security, Foucault therefore says, 'involves organizing, or anyway allowing the development of ever wide circuits'. New elements are constantly drawn into its concern as the mapping, profiling patterning and probabilistic analysis of the incidence of contingent events and the aleatory distribution of contingent behaviour among populations gathered pace.

As this story proceeds, in particular through the first half of the Security, Territory, Population series, Foucault tracks its emergence also through the economic debates which occurred between the mercantilists and the physiocrats which preceded the emergence of liberal economic thought and the advent, in addition to 'population', of another new social reality; that of the notion of 'the economy' itself, and of its market mechanisms. Key to these political economy debates was of course the question of freedom (BoP).

Whereas the basic function of discipline was to prevent everything 'even and above all the detail', the function of security was to rely on details that were not intrinsically good or bad but necessary; inevitable, as with so-called natural processes; crucially those of contingently correlated circuits of production and

45 For example see Saskia Sassen, The Global City (Princeton, NJ: Princeton University Press, 1991).

46 Colin McInnes once made the acute point that a biopolitics of security must have to contend also with the microbiological. He was right. Without enframing his pioneering work within the biopolitical analytic of security he has nonetheless provided powerful evidence of its operationalisation in health, security and foreign policy. See Colin McInnes, Health and Foreign Policy in the UK: The Experience since 1997 (London: The Nuffield Trust, 2005), Colin McInnes, Health, Security and the Risk Society (London: The Nuffield Trust, 2005); Colin McInnes and Kelley Lee, Health, Foreign Policy and Security (London: The Nuffield Trust, 2003). So also has Stefan Elbe, 'Strategic Implications of HIV/AIDS', Adelphi Paper No. 357, International Institute for Strategic Studies (Oxford: Oxford University Press, 2003); Stefan Elbe, 'HIV/AIDS and Security', in A. Collins (ed.), Contemporary Security Studies (Oxford: Oxford University Press, 2006); Stefan Elbe, 'AIDS, Security, Biopolitics', International Relations, 19:4 (2005), pp. 403-19 and Nikolas Rose, The Politics of Life Itself: Biomedicine, Power and Subjectivity in the Twenty-First Century (Princeton, NJ: Princeton University Press, 2007). 
reproduction, economic and sexual, micro- as well as macro-biological, material as well as immaterial. And while such details may not be pertinent in themselves, they may be combined in ways that deliver up pertinent information, at the general level of aggregation associated, for example, with population. Biopolitical security apparatuses did not therefore side with what was to be prevented or what was to be made obligatory by law. Their referent object was instead a new 'reality'; one increasingly understood to be the very contingent taking the place of things. The sociotechnical mechanisms which began taking this reality as their referent epistemic object could nonetheless also be put at the disposal of sovereigns; who, of course, frequently sought to finance them. Evaluating also whether or not such eventalness was desirable, biopolitical security mechanisms were designed to make things operate by regulating how their aleatory features contingently correlated. One might now say that biopolitics of security emerged as an early form of so-called 'effects' and 'evidence-based' operation.

This very tight correlation of biopolitical security apparatuses with contingency, eventalness, economy and circulation is, Foucault also says, profoundly linked to the rise of liberalism as a regime of power relations (the general thematic of $\mathrm{BoP}$ ); acting so that reality develops, is free to go its own way, follow its own course according to laws and dynamics amenable to epistemic interrogation and thus ultimately also to modulated policy intervention. In short, security was fundamentally correlated with a certain understanding of freedom as well. This freedom, he was careful to gloss, is not concerned with the exemptions and privileges that attach to a person. It concerned instead the very possibility of movement, change of place, and so on. Above all, and in summary form, it was the freedom of circulation, and the freedom to circulate, in the very broadest sense of the term. Abstracting further from Foucault's account one might therefore say that the problematic of biopolitical security apparatuses is fundamentally that of securing the contingent freedom of circulation. That is how and why we are now able to understand the epigraph which heads this article: biopolitically, 'freedom is nothing else but the correlative of the deployment of apparatuses of security' ${ }^{47}$

Peculiarly characteristic in particular, therefore, of liberal governmental power, power operated here in ways that mimicked currency rather than mechanics (BoP). Its logic was similarly more strategical than dialectical. Dialectical logic presupposes contradictory terms that are nonetheless situated within a realm which is ultimately homogenous. For two propositions to be contradictory or not, it is necessary, as Leibniz says, that they have something in common on the basis of which they can contradict one another. Strategic logic presupposes, instead, that it is possible to connect different terms productively, which terms nonetheless remain disparate (STP). Think, for example, of the disparate terms which risk analysis combines into the mathematical commodification of contingency. Between the disparate, contradiction does not even remain possible; but productive correlation does. The

\footnotetext{
47 A large question opens up here. It not only concerns the relation between what we might call an Epicurean account of freedom - whose mark is that of the clinamen or swerve in being and beings - and a biologised account of freedom whose mark is that of circulation. It also concerns the complex ways in which the politically 'progressive' embracing of the Epicurean meets the politically 'regressive' embracing of the biological in a confluence which greatly complicates late modern accounts of freedom, form and event. See Tim O'Keefe, Epicurus on Freedom (Cambridge: Cambridge University Press, 2005).
} 
productivity of strategic logic derives from connecting the heterogeneous into different cartographies of the contingent, rather than resolving the contradictory into higher forms of the same. Strategy is thus an ars combinatoria, presupposing an irredeemably heterogeneous universe, while Dialectic is an ars differentia presupposing a homogeneous one. Here, eventually, in the contemporary biopolitics of security in particular, the distinction between strategy and tactics becomes otiose, since according to contemporary understanding of what it is to be a living thing, and the art of living it, strategic logic is no longer telic but a recombinatorial art of design.

Foucault was therefore not only observing a change in the exercise of power and the conduct of conduct, when noting the emergence of the biopoliticality of liberal governmentality. He was also observing how such changes were taking place in correlation with complex changes in truth-telling practices concerning not only freedom but also uncertainty, the nature of the contingent as well, prospectively, as the very understanding of 'species' itself; including species as money, species as generic scientific taxonomy and species as biology. ${ }^{48}$ The space of problematisation of government was therefore also related, amongst other factors, to that of the changing problematisation of chance. These developments were in turn related to a changing biopolitical problematisation of both freedom and security in which while the referent empirical object of security was initially population rather than territory, it progressively became that of circulation tout court.

The question of contingency, or 'the aleatory', thus arises for Foucault as one of those factical elements or 'natural' processes to which liberal governmentality must attend, with which it must deal and in relation to which it has to regulate and evaluate its own performance and effectiveness in its ambition to exercise power over life. In governmental terms, the contingent features which life and populations display are not an ideological disguise for the operation of some hidden interests. Neither are they part of a dialectical historical process. They are a function of truth-telling practices of the life sciences and of the burgeoning sciences of uncertainty and risk. These perform a whole variety of governmental as well as scientific functions, not least in telling different stories about different categories of living things and their governability, as well as what falls into the category of living thing as such. ${ }^{49}$ It follows that changing biopolitical security mechanisms of the biopolitical economy of security are characteristically concerned with the random elements displayed by life in general, and populations in particular.

Foucault concludes by stating that biopolitics tout court simply is a dispositif de sécurité ${ }^{50}$ Biopolitics of security do not preserve and protect in the classical sense of security. They promote and regulate. The reason is simple. Classical security discourse presumes - by one means or another - that it is dealing with a fixed object. Biopolitical security discourses and techniques deal with an object that is continuously undergoing transformation and change through the manifold circuits of production and reproduction which comprise the very eventalness of its biological

48 Dillon, 'Governing Through Contingency: The Security of Biopolitical Governance', Geoffrey Poitras, The Early History of Financial Economics, 1478-1776 (Cheltenham: Edward Elgar Publishing, 2000), p. 522.

49 Michael Dillon, Politics of Security: Towards a Political Philosophy of Continental Thought (London: Routledge, 1996).

50 Foucault, Security, Territory, Population, Lecture 2. 
existence. Biopolitics thus secures by instantiating a general economy of the contingent throughout all the processes of circulation which impinge upon species existence. ${ }^{51}$ That is why we can now say that in an age gone global the biopolitical problematisation of security has become the imperial struggle not simply to seize territory, control resources or even reconfigure state apparatuses - although these remain traditional security concerns - but to secure the changing and manifold processes of global circulation as such.

No politics of life could remain unaffected by the impact which the changing demography of population and the molecularisation of biology have, however, had on life as species-being during the course of the 20th century. Biopolitics has not only therefore been transformed by what the life sciences understand a living thing to be, and how life processes can be manipulated by them in order to extend and promote the fructification and vitality of living material, it has similarly also been transformed by what has been happening to the populations of developed societies. Population dynamics and the life sciences are moreover complexly related. Across Atlantic societies, these developments are currently revolutionising the biopolitical security technologies of health management as much as they are those of military strategic discourse, ${ }^{52}$ the War on Terror, ${ }^{53}$ Homeland Security, ${ }^{54}$ National Resilience Strategies ${ }^{55}$ and allied corporate security practices. ${ }^{56}$

Specifically, the promise of molecular medicine allied to what health professionals call 'the compression of morbidity' among developed populations has already begun to transform the biopolitics of life itself. We deal briefly with the compression of morbidity in the next section and with the molecularisation of biology at a little greater length in the section after that. Space does not allow a fuller account of either development so our primary concern is to move towards outlining how these developments began to inaugurate a recombinant biopolitics of security, whose generative principle of formation is not simply species-being but species-being as what molecular biologists would call 'pluripotent' life. Such population dynamics and molecular science are also in the process of being complexly related through the pursuit of biomedicine. Whereas the genetic revolution has received the most publicity, the compression of morbidity has been no less influential at micro and macro levels in transforming the biopolitical rationalities and security technologies of the last century.

51 Dillon, 'Governing Through Contingency: The Security of Biopolitical Governance'.

52 Arquilla and Ronfeld, In Athena's Camp: Preparing for Conflict in the Information Age; John Arquilla and David Ronfeld, Swarming and the Future of Conflict (Santa Monica, CA: Rand Corporation, 2000).

53 Biersteker and Eckert, Countering the Financing of Global Terrorism; US General Account, Terrorist Financing: On Deterring Terrorist Operations in the US (Cosimo-on-Demand, 2005); Melinda Cooper, 'Pre-empting Emergence: The Biological Turn in the War on Terror', Theory, Culture, Society, 23 (2006), pp. 113-35; Maurice Greenberg, William F. Wechsler and Lee S. Wolosky, Terrorist Financing: Independent Task Force Report Brookings Institution, 2003).

$54\langle$ http://www.dhs.gov/dhspublic/ $\rangle$.

$55\langle$ http://www.ukresilience.info/index.shtm〉.

56 Michael Dillon, 'Virtual Security: A Life Science of (Dis)order', Millennium: Journal of International Studies, 32 (2003), pp. 531-58; Michael Dillon, 'Intelligence Incarnate: Martial Corporeality in the Digital Age', Body and Society, 9 (2002). 


\section{Population: the compression of morbidity}

In a now widely celebrated essay first issued as a keynote address to the US Institute of Medicine at the National Academy of Sciences in Washington in 1982, the American physician James Fries presented a paper concerning 'the compression of morbidity' which he claimed had transformed morbidity throughout the populations of the United States and Western Europe during the course of the twentieth century. ${ }^{57}$ The changes to which he referred, together with simplicity and eloquence of the thesis that he presented, continues to structure and inform biopolitically focused health policies today. Fries' thesis was as follows.

Western societies entered the 20th century in an era of infectious disease. In the United States, for example, tuberculosis was the number one killer while small pox, diphtheria, tetanus and other infectious diseases were prevalent. Curative medicine, allied to other biopolitical 'social' security strategies, transformed the morbidity of Western populations, however, by virtually eliminating such diseases. Consequently, an entirely different demographic of morbidity has emerged. This new landscape is characterised by chronic rather than infectious diseases. Chronic diseases are in turn distinguished by a variety of significantly different features from those which characterised infectious disease. These features include the following.

1. First, susceptibility to chronic illness is a universal among Western populations.

2. Second, chronic illnesses are characterised by early onset.

3. Third, chronic illnesses are progressive.

4. Fourth, such illnesses become clinically explicit only at certain symptom thresholds; angina or heart attack signalling the presence, for example, of heart disease that has been developing for many years.

5. Fifth, chronic illnesses are multifactorial.

6. Sixth, differences between individuals are manifested by the rate at which such diseases progress rather than the bald presence or absence of the disease.

7. Seventh, the onset and rate of progress of chronic illness is a direct function of exposure to risk factors. These in turn are very much a function of how lives are lived: 'life styles'.

Whereas infectious disease invited drug cures, chronic illnesses invite pre-emption and prevention together with medical campaigns aimed at changing life-styles, backed by widespread use of surveillance (or 'screening' in medical terms) and the statistical documentation of the incidence of disease distribution spatially as well as temporally. All these developments have in turn begun to be combined with the pervasive regulation and management of risk, and the astonishingly greater resolution given to the analytic of risk which resonates throughout all aspects of Western society. Closely allied with the concern for risk factors arising from life-styles, is an intense individualisation and personalisation of medicine as well. Whereas Foucault spoke of the ways in which liberal biopolitical governmentality encouraged the development of the entrepreneurial self, 58 the compression of morbidity witnesses the emergence of a self entrepreneurially responsibilised to secure its own health care.

\footnotetext{
57 James Fries, 'The Compression of Morbidity', The Milbank Quarterly, 83 ([1983] 2005), pp. 801-23; James F. Fries, 'Measuring and Monitoring Success in Compressing Morbidity', Annals of Internal Medicine, 139 (2003), p. 455; James F. Fries, 'Frailty, Heart Disease, and Stroke: The Compression of Morbidity Paradigm', American Journal of Preventive Medicine, 29 (2005), p. 164.

58 Foucault, Sécurité, Territoire, Population.
} 
Such developments similarly also reflect the intense preoccupation in military corporate and homeland security domains with the same kinds of preoccupations and analytical devices allying screening and surveillance with distribution-patterning and risk analysis across mass populations locally as well as globally. The biopoliticisation of security discourse in these more traditional areas of security analysis also reflects a massive shift to pre-emptive and preventative strategies. While we do not have the space to trace the connections, the correlation is no mere accident. Granted that both military and corporate strategies are driven by their own local and global dynamics, their informationalisation and biologisation nonetheless also directly reflects these developments as well. ${ }^{59}$ The reason we maintain this is that they not only borrow from, and leach into, one another. They share a similar if diffuse account of the 'real'.

Fries also argued, however, that Western societies are entering a new health phase in which the significance of chronic diseases will also decline as these in turn yield to well-targeted health policy interventions. Once such biopolitical strategies take effect, he claims, the onset of chronic illness will be delayed and its progress controlled by advances in molecular medicine and new genetically informed pharmacological regimes. Life expectancy is then expected to rise towards the figure of absolute life span. The duration of chronic illnesses would thus be shortened and death would result from the exhaustion of the reserve capacity of the vital organs rather than the lethality of chronic illness. Ideally, for Fries, people could therefore expect to live - actively and well - until the onset of terminal decline, which would be short and if not sweet at least brief and less distressing than years of incapacity. By these means life potential and not just life expectancy would be maximised. That, precisely, is what he meant by 'the compression' of morbidity. From a biopolitical perspective, 'senescence' - the ageing process itself - is already becoming an increasingly important security problematic for biopolitical regulation by actuaries and underwriters, for example, in that classic biopolitical security technology of insurance; as well as for health scientists, health professionals, and health managers.

\section{Recombinant biopolitics: securing 'pluripotent life'}

As life, and so-called 'life-styles', change, then so also will the regime of biopolitics to which life itself is subject. Just as population has changed, so also has life. In the molecular age life is no longer simply the life of population as Foucault documented their emergent biopolitical regulation at the beginning of the 18th century. Life in the molecular age already poses a new reality to and through biopolitics, because molecular science has transformed what we understand a living thing to be. It has also revolutionised the very intersections of life and death, including lives on the margin. Lives on the margin in fact become a prevailing concern locally as well as globally, politically as well as medically, socially as well as economically. Marginal life seems no longer 'marginal' but, as with failed states, rogue states and terrorising dissidents coursing through the capillary infrastructures of global society, embryonic

59 Cooper, 'Pre-empting Emergence', Michael Dillon and Julian Reid, 'Global Liberal Governance: Biopolitics, Security and War', Millennium: Journal of International Studies, 30 (2001), pp. 41-66. 
life or the material and ethical dilemmas posed by comatosed patients, marginal life emerges as central organising category in the biopoliticised power relations and continuous policy preoccupation of biopolitical governmentality. Increasingly characterised by a preoccupation with hetero-genesis, recombinant biopolitics is as concerned with pre-life as it is with post-life as it pursues its vocation of making life live.

The molecularisation of life has equally transformed what we are capable of doing to and with living material; the term pluripotent, for example, which we apply to the concept of life so characteristic of the molecular age, is derived from its use by molecular biologists to describe the potentiality of stem cells. Beyond the molecular and into the nano age techno-science is pursuing the possibility of recombining all materiality - organic and inorganic - thorough manipulating it at the level of its common atomic structure. In these, and other ways, life itself has come to be profoundly problematised by the arts less of 'life' than of 'animation'. Recombinant biopolitics is the biopolitics of the molecular age because what matters here is not simply life's molecular structure but the massive advance which has also been made in exposing the mechanisms of hetero-genesis as such; that which in 'truth' makes life live for the molecular age.

Particularly in respect of bioscience and biomedicine, currently now exemplified by the field of regenerative medicine in general and that of tissue engineering and stem cell research in particular, we are entering an age in which scientific knowledge does not merely seek to represent the truth of life. ${ }^{60}$ Nor is its ambition simply to manipulate life forms. The molecularisation of biology has radically extended our ambitions in respect of species existence; to control and command the morphogenetic process itself. Its ambition is not simply to manipulate specific actualisations of life, but to control the very production of living material irrespective of the specific forms in which it comes. In the process, its rendition of life has also changed. Life becomes equated with its pluripotency, and the object of biopower becomes preoccupied not only with strategies of resilience, self-repair and regeneration but also of instigating new life forms.

Following biological research into stem cells and tissue engineering, for example, life is more characteristically to be understood now as a pluripotent phenomenon. Pluripotent, here, means containing the capacity for regeneration and renewal through processes of self-differentiation via recombination. As Melinda Cooper has observed, operating at the forefront of biomedicine, Tissue Engineering does not simply concern itself with the transplantation of frozen forms and rigid bodies. ${ }^{61}$ Its target is organogenesis itself:

The operative question can be posed as follows: In response to what forces and tensions, and at what threshold, will an ensemble of cells, defined by variable relations of adhesion or disconnection, fold into a particular morphological form and acquire particular cellular properties? Regenerative medicine works through the continuous variation of force fields and it is from this level up that it attempts to determine the emergence of particular tissue qualities (density, compressibility, elasticity) properties and forms (cell morphology and

${ }^{60}$ Melinda Cooper, 'Resuscitations: Stem Cells and the Crisis of Old Age', Body Society, 12 (2006), pp. 1-23, Catherine Waldby, 'Umbilical Cord Blood: From Social Gift to Venture Capital', BioSocieties, 1 (2006), pp. 55-70.

61 Melinda Cooper, Surplus Life: Biotechnics and the Transformations of Capital (Washington, DC: Washington University Press, 2007). 
differentiation, organ morphology and structure). These forces might be biochemical, hydrodynamic or mechanical in nature. ${ }^{62}$

In the process of explaining the transformation of molecular biology, Cooper enables us to ask what happens to security processes which take life as their referent object when life comes to be understood and formed by processes which replace, "the technics of reproduction and substitution with an art of continuous modulation, in which form is plunged back into process, becoming continuously remorphable'. ${ }^{63}$

Security practices informed by understandings of living matter as a function of force fields of morphogenesis are not prophylactic practices. Regeneration rather than protection is more their condition of operation. Transformation rather than preservation is their object. They become preoccupied instead with securing (which now means engendering and manipulating) the contingent correlation of the events through which life-forms morph and change. If Foucault's original exploration of biopolitics' dispositif de sécurité identified the very eventalness of species existence as one of the base analytical categories of its biopoliticised security practices, molecularity has transformed eventalness as well. Its recombinant biopolitics is preoccupied with what we might call the securing of living material in its intrinsic 'pluripotence' as 'transformation event'. ${ }^{64}$ The biopolitical securing of pluripotent life is thus concerned less with subjecting it to safety measures than with commanding its infinitely regenerable design. As the author of one recent overview put it:

the fundamental principle of reparative medicine which governs our efforts to regenerate differentiated tissue is to organise the reparative circumstances to recapitulate the selected aspects of embryonic developmental sequence, including attempts to mimic the embryonic microenvironment in which tissue initiation, formation and expansion take place. ${ }^{65}$

As scientific historians at the Max Planck institute continually now also reminds us, molecular re-engineering is not simply aimed at the modification of metabolic processes but at their reprogramming: 'For the first time, it is on the level of instruction that metabolic processes are becoming susceptible to manipulation. Until that point was reached, medical intervention, even in its most intrusive physical, chemical and pharmacological forms, was restricted to the level of metabolic performance'. ${ }^{66}$ What regenerative medicine wants to elicit, Cooper concludes, 'is the generative moment from which all possible forms can be regenerated . . . the moment of emergence in which all forms are virtually infolded.' ${ }^{67}$ The referent object of biopolitical security strategies in the molecular age increasingly revolve around a new referent object of security, the moment of emergence considered independent of its actualisation.

When life is reduced to code and the code has been mastered, then the recruitment of life into its techno-scientific manipulation and biopolitical strategisation shifts

62 Ibid., p. 120.

63 Ibid., p. 123.

${ }^{64}$ Lezaun, 'Creating a New Object of Government: Making Genetically Modified Organisms Traceable', Social Studies of Science, 36 (2006), pp. 499-531.

65 Caplan (2002), p. 207, quoted by M. Cooper, Surplus Life: Biotechnics and the Transformations of Capital, p. 130.

${ }^{66}$ Hans-Jorg Rheinberger, 'Beyond Nature and Culture: Modes of Reasoning in the Age of Molecular Biology and Medicine', in M. Lock, A. Young and A. Cambrosio (eds.), Living and Working with the New Medical Technologies (Cambridge: Cambridge University Press, 2000 [1996]), pp. 19-30, p. 25.

${ }^{67}$ Cooper, Surplus Life: Biotechnics and the Transformations of Capital, p. 137. 
from the manipulation of forms of life into the command of regeneration itself. For these reasons we seem to be entering a new biopolitical order of the real in relation to the experience of the real now afforded by a recombinant biopolitical consensus revolving around molecular structure and hetero-genetic transformation. Once understood in terms of its recombinatory mechanisms, life becomes a matter of continuous mobile recomposition. When its science becomes less a matter of representation than of experimentation and design so also do its recombinant biopolitical security practices. ${ }^{6}$ Posing the question, what happens to security processes which take life as their referent object when life goes molecular? our answer is that a recombinant biopolitics of security emerges oriented towards becoming an experimental scientific art of design.

\section{Molecularisation: the recombinant biopolitical economy of life and death}

The biopolitical economy of security has therefore undergone profound change since Foucault first began its analysis. While the base analytical categories which he identified appear to remain the same - circulation, economy, eventalness and above all contingency-their operationalisation in the form of specific problematics, political rationalities and governmental technologies now ranges from the global to the molecular. We have space to offer only one additional reflection on them. That reflection is this. The pluripotent life of recombinant biopolitical economy of security pluralises and problematises death as much as it does life. Together with the compression of morbidity it is now also offering a novel problematic for that economy; one around which new political rationalities and governmental technologies from health policy to life and health insurance are already beginning to revolve. That problematic is the very interface of life and death: from the pre-birth pluripotency of stem cells to the pre-death aging of senescence. Recall our primary conclusion which is in any event worth restating here. Biopolitics of security secure by instantiating a general economy of the contingent throughout all the processes of reproductive circulation which impinge upon species existence as a whole.

In an age transforming age itself, through the alliance of morbidity's compression with the regenerative promises of molecular medicine, the very contingency calculus of the biopolitical economy of contingency which characterises the dispositif de sécurité of biopolitics is thus being reworked in the context of the changing correlation of life and death prompted by the molecular revolution in particular. Despite his differentiation of power over life from power over death, Foucault was well aware of the correlation of life and death. In the celebrated chapter on 'Right of Death and Power over Life' in The History of Sexuality, Foucault makes a variety of careful observations about the sovereign right over death and its development in response to the advent of biopolitics. The first is that it was never 'an absolute privilege'. ${ }^{69}$ The second and more directly important is that with the advent of biopolitics: 'There has been a parallel shift in the right of death, or at least a tendency to align itself with the exigencies of a life administering power and to define itself

${ }_{68}^{6}$ Dillon and Reid, 'Global Liberal Governance: Biopolitics, Security and War', p. 2.

${ }^{69}$ Foucault, The History of Sexuality, Vol. 1: The Will to Knowledge, p. 135. 
accordingly', ${ }^{70}$ Pre-birth, pre-death (senescence) and the post-death of the comatosed neither dead nor alive, is precisely that domain where this formidable power of death, 'now presents itself as the counterpart of a power that exerts a positive influence on life, that endeavours to administer, optimise, and multiply it, subjecting it to precise controls and regulations' ${ }^{71}$ In assigning itself the power of administering life in and through its radical contingency, the biopolitics of security now administers the threshold of life/death: including, in particular, the new formation of life and the prolonged forestalling of death. ${ }^{72}$

\section{Conclusion: the biopolitical freedom of security}

A complex pact was therefore struck between security, knowledge and freedom in the modern age. The modern political imaginary has been circumscribed by the complex permutations through which that pact has mutated. Hitherto, our understanding of the pact has largely been dominated by the political discourse of the subject, of possessive individualism, and the political bond said to be contracted between the political subject and the modern state. But there are many ways in which the modern understands and promotes freedom, not least because the genealogy of freedom upon which the modern relies is as rich in Epicurean as it is, for example, in Cartesian, Hobbesian or Kantian motifs. Thus, the natural philosophy of early-modern Europe found in Lucretius's De Rerum natura, for example, an argument allowing the association of an inexplicable and unpredictable or uncaused swerve in the flow of originary matter (the clinamen) with the possibility of free will. ${ }^{73}$ Foucault also observed that modern accounts of freedom in the 17th and 18th centuries were not only conceived in terms of natural rights, or the rights of the citizen and the subject. They were also conceived in terms of what might be called the developmental freedom of its biopolitics. ${ }^{74}$

What follows for freedom similarly also follows for security. Modern conceptions of security have never been confined to the discourse of a subject presumed to exist prior to the power/knowledge relations that constitute it as the subject that it is; however that subject is conceived and at whatever level, individual or collective, it is presumed to operate. As he teaches us about the heterogeneity and problematicity of discourses of modern power, so also Foucault teaches us about the heterogeneity and problematicity of modern accounts of security and freedom; which teaching requires us in response to the provocation of Foucault not simply to apply Foucault but to go beyond Foucault in relation especially to power/knowledge, freedom and security. Foucault thereby not only extended the register of what such practices meant and

70 Ibid., p. 136.

71 Ibid., p. 137.

72 See the challenging essays, for example, in James Franklin, The Science of Conjecture: Evidence and Probability before Pascal (Baltimore, MD: John Hopkins University Press, 2001), p. 497.

73 See Serres, The Birth of Physics.

74 Abiola Senok, Phil Wilson, Margaret Reid, Anne Scoular, Neil Craig, Alex McConnachie, Bridie Fitzpatrick and Alison MacDonald, 'Can We Evaluate Population Screening Strategies in UK General Practice? A Pilot Randomised Controlled Trial Comparing Postal and Opportunistic Screening for Genital Chlamydial Infection', Journal of Epidemiological Community Health, 59 (2005), pp. 198-204, provides an eloquent contemporary example. 
did. In the process he also alerted us to how the changing experiences of the real which characterised the diverse complex of heterogeneous power relations characteristic of modern power relations were also deeply implicated in the detailed regulation of life locally and globally.

Foucault therefore identified a different correlation of security and freedom than that which characterises the West's traditional politics of security, founded as it is on an allied politics of the subject. ${ }^{75}$ There could be no more central question for politics, therefore, than that of the relation of freedom and security. While the very mythos of the modern state is founded in its claim to be a security provider, and the modern's commitment to life is founded in the promotion of life, their respective security mechanisms seem nonetheless fated to threaten the very ideal of political order and the very valuation of life which they are supposed to advance. What is well understood now in relation to the geopolitics of state security is evident also in the biopolitics of security. Consistently hailed as part of the solution to the problematics of politics, freedom and justice, modern practices of security have consistently proved themselves to be part of the problem instead. This applies as much to biopolitics as to geopolitics.

In order to promote life, biopolitical security practices must of course come to know life. But they do not simply insist on rendering life transparent to certain forms of knowing; such life which is in whatever way resistant to being known begins to pose a security problem to biopolitics. Their purpose is in addition of course to weigh life - to conduct a continuous assay of life - in order to determine which life is capable of self-regulating itself in the cause of its self-improvement, adaptation and change; and which forms of life have most to teach about these processes offering a kind of best practice of living and preferred forms of life. Different life forms display differing capacities in this respect. It therefore follows that some forms of life may be less capable or incapable, and even hostile or resistant, to self-regulating themselves in the cause of their self-improvement and adaptation. All life in some degree or another may have to be coached in its biopolitical self-governance and some life may have to be subject to more than coaching. Recalcitrant and intransigent forms of life may require punishment and correction. Ultimately some life forms may be regarded as inimical to life itself and these will have to be eliminated. Foucault explores this logic and illustrates its operation in the account that he gives of race war (SMD). Others have illustrated it by reference to poverty programmes. ${ }^{76}$ 'Making life live' is as violent in its way as power over death.

The problematic of modern politics is therefore subtly misconceived when freedom and security are construed exclusively as contending values locked in a zero-sum game in which the one is advanced or lost at the expense of the other. Security is not opposed to freedom when freedom is understood as the contingent developmental freedom of biological existence. In its biological contingency, security does not possibilise freedom and freedom is not designed to constrain security. Here, instead, security becomes a set of mechanisms self-governing the very contingent properties of the freedom which biological entities are said to display; aspiring to autopoietic and

75 Giorgio Agamben comes close to doing so as well: 'Nothing is therefore more important than a revision of the concept of security as the basic principle of state politics', Agamben, Homo Sacer, Sovereign Power and Bare Life.

${ }^{76}$ Barbara Cruikshank, The Will to Empower: Democratic Citizens and Other Subjects (Ithaca, NY: Cornell University Press, 1999). 
complex adaptive systemic forms of freedom generically implicated in varying accounts of becoming, and of the continuous individuation of form. In the process, freedom becomes the principal mechanism by which biopolitical security is secured. Free to make life live freely, biopolitics of security will and do enforce that project violently. Through the regulation and enactment of the very aleatory character of species existence, modern freedom is the mechanism by which security is forcefully biopoliticised in the name of promoting the life and potentiality of the species. It does so, according to Foucault, to the point of its self-immolation. In Volume 1 of The History of Sexuality, he observes how a certain threshold of modernity is reached when it comes to wager the life of the species on its own (bio) political strategies. Only when the interrogation of security acknowledges that it must become an interrogation of the intimate operational correlation of security and freedom in the biopolitics of security will it begin to engage the aporia of security which threatens the very project of political modernity itself; that in seeking to secure the promotion of human being as species being, modern security practices threaten its very existence. Making live is a lethal business. Paradoxically, freedom from it may be required if species life is in fact to out-live its grip. 